\title{
Cardiac magnetic resonance imaging in primary PCI: additional value?
}

\author{
E. E. van der Wall $\cdot$ J. J. Bax $\cdot$ J. W. Jukema \\ M. J. Schalij
}

Received: 14 April 2009/ Accepted: 16 April 2009/Published online: 26 May 2009

(C) The Author(s) 2009. This article is published with open access at Springerlink.com

Cardiac magnetic resonance imaging (CMR) has long been recognized as an accurate and reliable means of evaluating cardiac anatomy and ventricular function. Considerable progress has been made in the field of CMR, providing accurate evaluation of left ventricular function parameters in coronary artery disease, heart failure, hypertrophic cardiomyopathy, and many other cardiac diseases [1-11]. Stress first-pass contrast-enhanced myocardial perfusion CMR can be used to detect subendocardial ischemia and recent studies have demonstrated the high diagnostic accuracy of stress myocardial perfusion CMR for detecting significant coronary artery disease [12-17]. Magnetic resonance angiography (MRA) has been introduced as a method that can provide visualization of all three major coronary arteries, coronary anomalies, coronary bypasses and the aorta within a single three-dimensional acquisition [18-21]. CMR has become the first choice imaging modality in complex congenital heart disease [22-26] and imaging great vessels [27, 28].

Editorial comment to the article of Larose et al. (doi: 10.1007/s10554-009-9451-4).

E. E. van der Wall ( $₫)$ · J. J. Bax · J. W. Jukema • M. J. Schalij

Department of Cardiology, Leiden University Medical Center, P.O. Box 9600, Leiden, The Netherlands

e-mail: e.e.van_der_wall@lumc.nl
Over the past years, contrast-enhanced CMR has been used to visualize the transmural extent of myocardial infarction with high spatial resolution [29-34]. Infarcted myocardium appears hyper enhanced compared with normal myocardium when imaged by a late enhancement MRI technique with the use of T1-weighted sequence after injection of gadolinium chelates. Late gadolinium-enhanced CMR can clearly delineate subendocardial infarction and the transmural extent of delayed enhancement potentially predicts functional outcome after revascularization in acute myocardial infarction and chronic ischemic heart disease [35, 36].

In a recent issue of the International Journal of Cardiovascular Imaging, Larose et al. [37] investigated the value of contrast-enhanced CMR in patients following primary percutaneous coronary intervention (PCI) because of ST-segment elevation myocardial infarction (STEMI). The first hours of STEMI are critical: the earlier patient evaluation is performedpreferably within hours - the more rapidly prognosisguiding therapies can be initiated. To determine whether CMR is effective in risk stratification in the hyperacute phase of STEMI, the feasibility and safety of CMR was studied in the hyperacute phase of STEMI immediately after primary PCI. A total of 128 consecutive patients immediately after primary PCI for STEMI, of whom 64 underwent CMR $12 \mathrm{~h}$ after primary PCI versus 64 matched controls. Outcomes were followed over 6 months. CMR in hyperacute STEMI was not associated with in-hospital death, 
infarct expansion, or urgent revascularization. CMR immediately after primary PCI did not increase nephropathy. CMR did not increase major adverse cardiac events (5 vs. $8 \%$ ) or recurrence of angina (6 vs. $8 \%$ ) at 6 months. It was concluded that CMR immediately after primary PCI is feasible and safe, allowing very early risk stratification in STEMI. In the current study [37] a very low event rate was recorded both inhospital and during the 6 months following CMR which was similar to that of primary PCI subjects not undergoing CMR.

Until now, only a few studies have evaluated the effects of primary PCI using contrast-enhanced CMR, mostly focused on the effects of stents on CMR imaging quality [38-40]. Kitabata et al. [41] showed in 27 patients with anterior acute STEMI that the microvascular resistance index, being a parameter of microvascular damage, measured immediately after primary PCI was a useful predictor for CMRdetermined infarct size. In the HEBE trial, a large, multicentre, randomized trial performed in The Netherlands, the effects of intracoronary infusion of autologous bone marrow mononuclear cells after primary PCI were evaluated with contrast-enhanced CMR both in the acute phase of STEMI and 4 months later [42, 43]. In these studies [41-43], CMR proved to be feasible and there were no safety concerns for CMR in the hyperacute phase.

The present study is therefore one of the leading studies to demonstrate the feasibility and safety of CMR in the hyperacute phase of STEMI after primary PCI. Very early risk stratification may be further refined safely by CMR, guiding the way for improved tapering of therapies-such as stem cell therapy-in the hyperacute phase of STEMI. Consequently, performing CMR in the acute phase of STEMI offers additional value in patients undergoing primary PCI.

Open Access This article is distributed under the terms of the Creative Commons Attribution Noncommercial License which permits any noncommercial use, distribution, and reproduction in any medium, provided the original author(s) and source are credited.

\section{References}

1. van der Wall EE, Vliegen HW, de Roos A, Bruschke AV (1995) Magnetic resonance imaging in coronary artery disease. Circulation 92:2723-2739
2. Bavelaar-Croon CD, Kayser HW, van der Wall EE et al (2000) Left ventricular function: correlation of quantitative gated SPECT and MR imaging over a wide range of values. Radiology 217:572-575

3. Bax JJ, Lamb H, Dibbets P et al (2000) Comparison of gated single-photon emission computed tomography with magnetic resonance imaging for evaluation of left ventricular function in ischemic cardiomyopathy. Am J Cardiol 86:1299-1305

4. Posma JL, Blanksma PK, van der Wall EE, Hamer HP, Mooyaart EL, Lie KI (1996) Assessment of quantitative hypertrophy scores in hypertrophic cardiomyopathy: magnetic resonance imaging versus echocardiography. Am Heart J 132:1020-1027

5. Pluim BM, Beyerbacht HP, Chin JC et al (1997) Comparison of echocardiography with magnetic resonance imaging in the assessment of the athlete's heart. Eur Heart J 18:1505-1513

6. Pluim BM, Chin JC, De Roos A et al (1996) Cardiac anatomy, function and metabolism in elite cyclists assessed by magnetic resonance imaging and spectroscopy. Eur Heart J 17:1271-1278

7. van der Wall EE, den Hollander W, Heidendal GA, Westera G, Majid PA, Roos JP (1981) Dynamic myocardial scintigraphy with $123 \mathrm{I}$-labeled free fatty acids in patients with myocardial infarction. Eur J Nucl Med 6:383-389

8. Braun S, van der Wall EE, Emanuelsson S, Kobrin I (1996) Effects of a new calcium antagonist, mibefradil (Ro 405967), on silent ischemia in patients with stable chronic angina pectoris: a multicenter placebo-controlled study. The mibefradil international study group. J Am Coll Cardiol 27:317-322

9. Holman ER, Buller VG, de Roos A et al (1997) Detection and quantification of dysfunctional myocardium by magnetic resonance imaging. A new three-dimensional method for quantitative wall-thickening analysis. Circulation 95:924-931

10. Schuijf JD, Bax JJ, Shaw LJ et al (2006) Meta-analysis of comparative diagnostic performance of magnetic resonance imaging and multislice computed tomography for noninvasive coronary angiography. Am Heart J 151:404-411

11. Ypenburg C, van der Wall EE, Schalij MJ, Bax JJ (2008) Imaging in cardiac resynchronisation therapy. Neth Heart $\mathbf{J}$ 16:S36-S40

12. van Rugge FP, van der Wall EE, Bruschke AV (1992) New developments in pharmacologic stress imaging. Am Heart J 124:468-485

13. van Rugge FP, Holman ER, van der Wall EE et al (1993) Quantitation of global and regional left ventricular function by cine magnetic resonance imaging during dobutamine stress in normal human subjects. Eur Heart J 14:456-463

14. Pluim BM, Lamb HJ, Kayser HW, Leujes F et al (1998) Functional and metabolic evaluation of the athlete's heart by magnetic resonance imaging and dobutamine stress magnetic resonance spectroscopy. Circulation 97:666-672

15. van Rugge FP, van der Wall EE, Spanjersberg SJ et al (1994) Magnetic resonance imaging during dobutamine stress for detection and localization of coronary artery disease. Quantitative wall motion analysis using a modification of the centerline method. Circulation 90:127-138

16. Nemes A, Geleijnse ML, van Geuns RJ et al (2008) Dobutamine stress MRI versus threedimensional contrast 
echocardiography: it's all black and white. Neth Heart J $16: 217-218$

17. Schuijf JD, Bax JJ, van der Wall EE (2007) Anatomical and functional imaging techniques: basically similar or fundamentally different? Neth Heart J 15:43-44

18. Vliegen HW, Doornbos J, de Roos A, Jukema JW, Bekedam MA, van der Wall EE (1997) Value of fast gradient echo magnetic resonance angiography as an adjunct to coronary arteriography in detecting and confirming the course of clinically significant coronary artery anomalies. Am J Cardiol 79:773-776

19. Hoogendoorn LI, Pattynama PM, Buis B, van der Geest RJ, van der Wall EE, de Roos A (1995) Noninvasive evaluation of aortocoronary bypass grafts with magnetic resonance flow mapping. Am J Cardiol 75:845-848

20. Langerak SE, Vliegen HW, de Roos A et al (2002) Detection of vein graft disease using high-resolution magnetic resonance angiography. Circulation 105:328-333

21. Rebergen SA, Ottenkamp J, Doornbos J, van der Wall EE, Chin JG, de Roos A (1993) Postoperative pulmonary flow dynamics after Fontan surgery: assessment with nuclear magnetic resonance velocity mapping. J Am Coll Cardiol 21:123-131

22. Groenink M, Lohuis TA, Tijssen JG et al (1999) Survival and complication free survival in Marfan's syndrome: implications of current guidelines. Heart 82:499-504

23. Tulevski II, Hirsch A, Sanson BJ et al (2001) Increased brain natriuretic peptide as a marker for right ventricular dysfunction in acute pulmonary embolism. Thromb Haemost 86:1193-1196

24. Niezen RA, Helbing WA, van der Wall EE, van der Geest RJ, Rebergen SA, de Roos A (1996) Biventricular systolic function and mass studied with MR imaging in children with pulmonary regurgitation after repair for tetralogy of Fallot. Radiology 201:135-140

25. Vliegen HW, van Straten A, de Roos A et al (2002) Magnetic resonance imaging to assess the hemodynamic effects of pulmonary valve replacement in adults late after repair of tetralogy of fallot. Circulation 106:1703-1707

26. Oosterhof T, van Straten A, Vliegen HW et al (2007) Preoperative thresholds for pulmonary valve replacement in patients with corrected tetralogy of Fallot using cardiovascular magnetic resonance. Circulation 116:545-551

27. van der Geest RJ, de Roos A, van der Wall EE, Reiber JH (1997) Quantitative analysis of cardiovascular MR images. Int J Card Imaging 13:247-258

28. van der Geest RJ, Niezen RA, van der Wall EE, de Roos A, Reiber JH (1998) Automated measurement of volume flow in the ascending aorta using MR velocity maps: evaluation of inter- and intraobserver variability in healthy volunteers. J Comput Assist Tomogr 22:904-911

29. van der Laarse A, Kerkhof PL, Vermeer F et al (1988) Relation between infarct size and left ventricular performance assessed in patients with first acute myocardial infarction randomized to intracoronary thrombolytic therapy or to conventional treatment. Am J Cardiol 61:1-7

30. de Roos A, Matheijssen NA, Doornbos J et al (1990) Myocardial infarct size after reperfusion therapy: assessment with Gd-DTPA-enhanced MR imaging. Radiology 176: 517-521

31. de Roos A, Matheijssen NA, Doornbos J, van Dijkman PR, van Rugge PR, van der Wall EE (1991) Myocardial infarct sizing and assessment of reperfusion by magnetic resonance imaging: a review. Int J Card Imaging 7:133-138

32. van Rugge FP, Boreel JJ, van der Wall EE et al (1991) Cardiac first-pass and myocardial perfusion in normal subjects assessed by sub-second Gd-DTPA enhanced MR imaging. J Comput Assist Tomogr 15:959-965

33. van Rugge FP, van der Wall EE, van Dijkman PR, Louwerenburg HW, de Roos A, Bruschke AV (1992) Usefulness of ultrafast magnetic resonance imaging in healed myocardial infarction. Am J Cardiol 70:1233-1237

34. Holman ER, van Jonbergen HP, van Dijkman PR, van der Laarse A, de Roos A, van der Wall EE (1993) Comparison of magnetic resonance imaging studies with enzymatic indexes of myocardial necrosis for quantification of myocardial infarct size. Am J Cardiol 71:1036-1040

35. van der Wall EE, Bax JJ (2008) Late contrast enhancement by CMR: more than scar? Int J Cardiovasc Imaging 24: 609-611

36. Nijveldt R, Beek AM, Hirsch A et al (2008) 'No-reflow' after acute myocardial infarction: direct visualisation of microvascular obstruction by gadolinium-enhanced CMR. Neth Heart J 16:179-181

37. Larose E, Côté J, Rodés-Cabau J et al (2009) Contrastenhanced cardiovascular magnetic resonance in the hyperacute phase of ST-elevation myocardial infarction. Int J Cardiovasc Imaging 25:519-527

38. Porto I, Selvanayagam J, Ashar V, Neubauer S, Banning AP (2005) Safety of magnetic resonance imaging one to three days after bare metal and drug-eluting stent implantation. Am J Cardiol 96:366-368

39. van der Hoeven BL, Pires NM, Warda HM et al (2005) Drug-eluting stents: results, promises and problems. Int $\mathbf{J}$ Cardiol 99:9-17

40. Syed MA, Carlson K, Murphy M, Ingkanisorn WP, Rhoads KL, Arai AE (2006) Long-term safety of cardiac magnetic resonance imaging performed in the first few days after bare-metal stent implantation. J Magn Reson Imaging 24: 1056-1061

41. Kitabata H, Imanishi T, Kubo T et al (2009) Coronary microvascular resistance index immediately after primary percutaneous coronary intervention as a predictor of the transmural extent of infarction in patients with ST-segment elevation anterior acute myocardial infarction. JACC Cardiovasc Imaging 2:263-722

42. van der Laan A, Hirsch A, Nijveldt R et al (2008) Bone marrow cell therapy after acute myocardial infarction: the HEBE trial in perspective, first results. Neth Heart J $16: 436-439$

43. Hirsch A, Nijveldt R, van der Vleuten PA et al (2008) Intracoronary infusion of autologous mononuclear bone marrow cells in patients with acute myocardial infarction treated with primary PCI: pilot study of the multicenter HEBE trial. Catheter Cardiovasc Interv 71:273-281 